\title{
Development and Performance of Dual Purpose Cook Stove
}

\author{
A.S. Ghadge*, N.D. Patil, A. J. Chopade, D.M. Rathi and A.V. Alaspure \\ College of Agricultural Engineering and Technology, Jalgaon (JA) Affiliated to Dr. \\ Panjabrao Deshmukh Krishi Vidyapeeth, India \\ *Corresponding author
}

\begin{tabular}{l} 
K e y w o r d s \\
$\begin{array}{l}\text { Dual purpose cook } \\
\text { stove, Biomass } \\
\text { combustion, Babul } \\
\text { and neem sticks }\end{array}$ \\
Article Info \\
$\begin{array}{l}\text { Accepted: } \\
\text { 18 May } 2020 \\
\text { Available Online: } \\
\text { 10 June } 2020\end{array}$ \\
\hline
\end{tabular}

\section{A B S T R A C T}

Biomass combustion provides basic energy requirements for cooking and water heating in the developing countries. Biomass is considered as the renewable energy source with the highest potential to contribute in the energy needs for both the developed and developing economics worldwide. The research work was undertaken to develop the dual purpose cook stove suitable for family size. The study revealed that the average thermal efficiency for dual purpose cook stove was found as 14.81 percent and 18.28 perusing babul sticks and neem sticks respectively and the power output ratings for dual purpose cook stove were found $1.56 \mathrm{~kW}$ and $1.69 \mathrm{~kW}$ respectively with babul sticks and neem sticks. Specific fuel consumption (SFC) wasfoundas0.326 and 0.297 for babul sticks and neem sticks respectively because of higher calorific value of babul sticks and neem sticks respectively i.e. $3796.8 \mathrm{kcal} / \mathrm{kg}$ and $3435.2 \mathrm{kcal} / \mathrm{kg}$. Mixture of fine and courses and was used as insulation for cook stove. In water heating, the temperature rise per unit length was $120 \mathrm{C} / \mathrm{m}$ and temperature rise per unit time was $12^{\circ} \mathrm{C} / \mathrm{min}$.

\section{Introduction}

Energy plays avital role in daily life. In India, most of the energy among total energy demand is used for cooking in domestic sector and it is fulfilled by using Abundantly available biomass. Biomass is considered as the renewable energy source with the highest Potential to contribute in the energy needs for both the developed and developing economics worldwide.
The estimates of MNRE indicate That 32 percent of the total primary energy issue in the country is derived from Biomass and more than 70 percent of population is dependent on biomass for the Energy needs. Traditional cook stoves or chulhas, which have efficiencies less than 10 percent and are known tube sources of large quantities of pollutants are used by most rural households in India for cooking. In such households, women and children are often exposed to high 
levels of pollutants, for 3 to 7 hours daily over many years. The smoke less and energy efficient cooking stoves still remains distant dream. The improved cooks stove is a combustion device through which cooking activity can be performed at country side. It has great potential to minimize emission and yield better fuel efficiency. This improved Cook stove is a dual purpose instrument i.e. It can be use be used for cooking as well as water heating. For being Energy efficient, the cook stove is provided with insulation of sand and small stones. For water heating purpose, a copper coil is provided in inner side of burning zone of cook stove. This water heater can be used for domestic purpose the cook stove has very less smoke formation and have high efficiency.

\section{Materials and Methods}

This cook stove is made with metal. This is developed at workshop and can be made very cheaply using local materials. This work was done by directing hot Gases from fuel wood fire up to cooking pot. A copper coil was provided inside the heating tunnel for simultaneous heating of water along with cooking.

\section{Methodology}

\section{Design and fabrication of dual purpose cook stove}

A dual purpose cook stove was developed for cooking as well as water heating with less smoke. The design specification of the dual purpose cook stove are given in Table 3.1 and Fig 3.1.

\section{Instrument action involved for performance evaluation of dual purpose cook stove}

An instrument involved for performance evaluation of dual purpose cook stove is discussed in the following section.

\section{Performance Evaluation of Dual Purpose Cookstove}

\section{Flame temperature}

It was observed that during Water Boiling Test, the maximum flame temperature using babul sticks and neem sticks as a fuel were $680^{\circ} \mathrm{C}$ and $877.2^{\circ} \mathrm{C}$ respectively. The volatile mater is inversely proportional to the flame temperature and the flame temperature depends upon the calorific value of the fuel.

\section{Water temperature}

It was observed that time required for water boiling temperature by using Babul sticks and neem sticks in natural convection was 22-25 minutes and 20-25 Minutes respectively.

\section{Stove Surface Temperature}

The average wall surface temperature of the dual purpose cook stove was increased as duration of burning was longer in natural convection. The maximum stove surface wall temperature obtained with the babul sticks and neem sticks during Water Boiling Test in natural convection were $68.6^{\circ} \mathrm{C}$ and $65.3^{\circ} \mathrm{C}$ respectively.

\section{Residues (Ash+Residues)}

After the burning of total feed stock in a cook stove, the ash produced by different feed stocks was weighed. For babul sticks and neem sticks, the average ash produced after WBT were found as $41 \mathrm{~g}$ and $39.66 \mathrm{~g}$ respectively. The total ash produced from the solid biomass depended on the type of biomass used.

\section{Unburned fuel weight}

After the burning offered stocks, the unburned 
fuel remained in feed stocks during the time of Water Boiling Test and Cooking Test was weighed. In Water Boiling Test for babul sticks and neem sticks, the total quantity of unburned fuel was found as $940 \mathrm{~g}$ and $500 \mathrm{~g}$ respectively .In Cooking Test ,for babul stick sand neem sticks the total quantity of unburned fuel was found as $750 \mathrm{~g}$ and $800 \mathrm{~g}$, respectively.

\section{Efficiency test}

Efficiency was determined by carrying out the Standard Water Boiling Test (WBT).Thermal efficiencies obtained for babul and neem sticks were 14.81 percent and 18.28 percent respectively.

\section{Power output rating}

The power output ratings found after Water Boiling Test for babul sticks and neem sticks were $1.56 \mathrm{~kW}$ and $1.69 \mathrm{~kW}$,resp. Typicaly, the minimum power requirement to cook meal for a family of 4-5 persons is about 1.5 to $2 \mathrm{~kW}$ with burning time about 1.0 to $1.5 \mathrm{hr}$.

\section{Cooking Test}

The actual cooking test was carried out to analyses the performance of developed dual purpose cook stove with traditional cooking methods using selected biomass i.e. babul stick sand neem sticks. The initial mass of $1 \mathrm{~kg}$ rice was taken and babul sticks and neem sticks was used as a fuel. The amount of fuels required to cook the rice was $0.750 \mathrm{~kg}$ and $0.700 \mathrm{~kg}$ for babul sticks and neem sticks. From Fig. the times pentin cooking of rice per $\mathrm{kg}$ of cooked food was $0.181 \mathrm{hr} / \mathrm{kg}$ and 0.163 $\mathrm{hr} / \mathrm{kg}$ for babul stick sand neem sticks, respectively and the specific fuel consumption (SFC) was calculated 0.326 and 0.297 for babul sticks and neem sticks, respectively. The developed cooking stove was found safe during operation and no difficulties were found at the time of cooking.

\section{Water heating test}

In water heating test, water in the tank with temperature $300 \mathrm{C}$ was carried

In to the copper tube of length $1 \mathrm{~m}$. The water left the tube with temperature of $420 \mathrm{C}$ i.e temperature rise is $120 \mathrm{C}$. Time taken to heat 1litre water was found to be $1 \mathrm{~min}$.

There fore, the temperature rise per unit length was $120 \mathrm{C} / \mathrm{min}$ temperature rise per Unit time was $120 \mathrm{C} / \mathrm{min}$.

\section{Results}

Table.1 Technical specifications of dual purpose cook stove

\begin{tabular}{llc}
\hline S. & \multicolumn{1}{c}{ Parameter } & Dimensions \\
\hline 1. & Height of combustion chamber, $\mathrm{m}$ & 0.18 \\
2. & Length of combustion chamber, $\mathrm{m}$ & 0.18 \\
3. & Cross-sectional area of combustion chamber, $\mathrm{m}^{2}$ & 0.025 \\
4. & Volume of combustion chamber, $\mathrm{m}^{3}$ & 0.0046 \\
5. & Height of stove walls, $\mathrm{m}$ & 0.25 \\
6. & Height of legs, m & 0.18 \\
7. & Outer diameter of stove & 0.2 \\
8. & Thickness of insulation, $\mathrm{m}$ & 0.05 \\
9. & Diameter of copper tube & 0.005 \\
10. & Length of copper tube & 1 \\
\hline
\end{tabular}


Table.1 A.Proximate composition of feedstock

\begin{tabular}{|l|c|c|c|c|c|}
\hline S.No & & $\begin{array}{c}\text { content,\% } \\
\text { (w.b.) } \\
\text { (Average) }\end{array}$ & $\begin{array}{c}\text { mater,\% } \\
\text { (Average) }\end{array}$ & $\begin{array}{c}\text { content,\% } \\
\text { (Average) }\end{array}$ & $\begin{array}{c}\text { carbon,\% } \\
\text { (Average) }\end{array}$ \\
\hline 1. & $\begin{array}{c}\text { Babul } \\
\text { sticks }\end{array}$ & 5.60 & 73.06 & 4.08 & 17.28 \\
\hline 2. & $\begin{array}{c}\text { Neem } \\
\text { sticks }\end{array}$ & 5.18 & 75.26 & 4.75 & 14.80 \\
\hline
\end{tabular}

Table.2 Ultimate composition of feedstock

\begin{tabular}{|c|c|c|c|c|c|}
\hline \multirow{2}{*}{$\begin{array}{c}\text { Sr. } \\
\text { No }\end{array}$} & \multirow{2}{*}{ Biomass } & \multicolumn{4}{|c|}{ Ultimate composition,\% } \\
\cline { 3 - 6 } & $\begin{array}{c}\text { Carbon } \\
\text { content, \% } \\
\text { (Average) }\end{array}$ & $\begin{array}{c}\text { Hydrogen } \\
\text { content, \% } \\
\text { (Average) }\end{array}$ & $\begin{array}{c}\text { Nitrogen } \\
\text { content, \% } \\
\text { (Average) }\end{array}$ & $\begin{array}{c}\text { Oxygen } \\
\text { content, } \\
\text { \% } \\
\text { (Average) }\end{array}$ \\
\hline 1. & Babul sticks & 63.56 & 6.77 & 0.6388 & 23.95 \\
\hline 2. & Neem sticks & 64.57 & 6.88 & 0.5948 & 24.22 \\
\hline
\end{tabular}

i) Performance Evaluation of Dual Purpose Cookstove

\begin{tabular}{|c|c|c|}
\hline Sr. No & Particular & Formula \\
\hline A & Proximate Analysis & Moisture content $(\% \mathrm{wb})=\frac{\mathrm{W}_{2}-\mathrm{W}_{3}}{\mathrm{~W}_{2}-\mathrm{W}_{1}} \mathrm{X} 100$ \\
\hline 2 & Moisture Content & Volatile Mater(\%)= \\
\hline 3 & Ash Content & Ash Content $\%=\frac{\mathrm{W}_{3}-\mathrm{W}_{4}}{\mathrm{~W}_{2}-\mathrm{W}} \mathrm{X} 100$ \\
\hline 4 & FixedCarbon & \\
\hline B & & Fixedcarbon(\%) $\mathrm{W}_{2}-\mathrm{W}_{1}$ \\
\hline
\end{tabular}




\begin{tabular}{|c|c|c|}
\hline 1 & CarbonContent & $\mathrm{C}=0.97 \mathrm{FC}+0.7(\mathrm{VM}-0.1 \mathrm{~A})-\mathrm{M}(0.6-0.01 \mathrm{M}), \%$ \\
\hline 2 & HydrogenContent & $\begin{array}{c}\mathrm{H}=0.036 \mathrm{FC}+0.086(\mathrm{VM}-0.1 \mathrm{~A})-0.0035 \mathrm{M}^{2}(1-0.02 \\
\mathrm{M})\end{array}$ \\
\hline 3 & NitrogenContent & $\mathrm{N} 2=2.10-0.020 \mathrm{VM}, \%$ \\
\hline 4 & OxygenContent & $\mathrm{O} 2=100-\%$ of $(\mathrm{C}+\mathrm{H}+\mathrm{N}+\mathrm{Ash}), \%$ \\
\hline
\end{tabular}

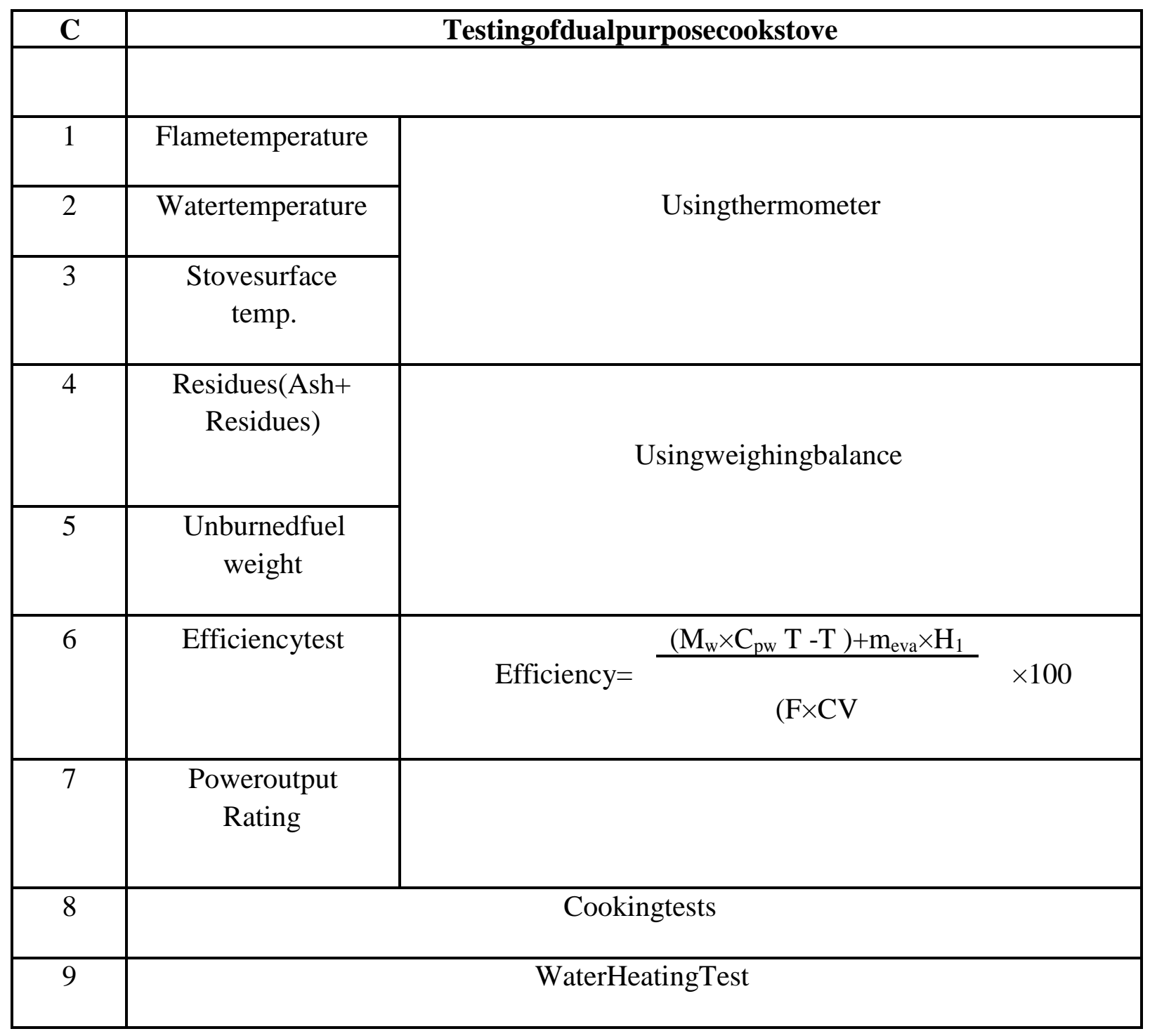


Fig.1 Duel purpose cook stove

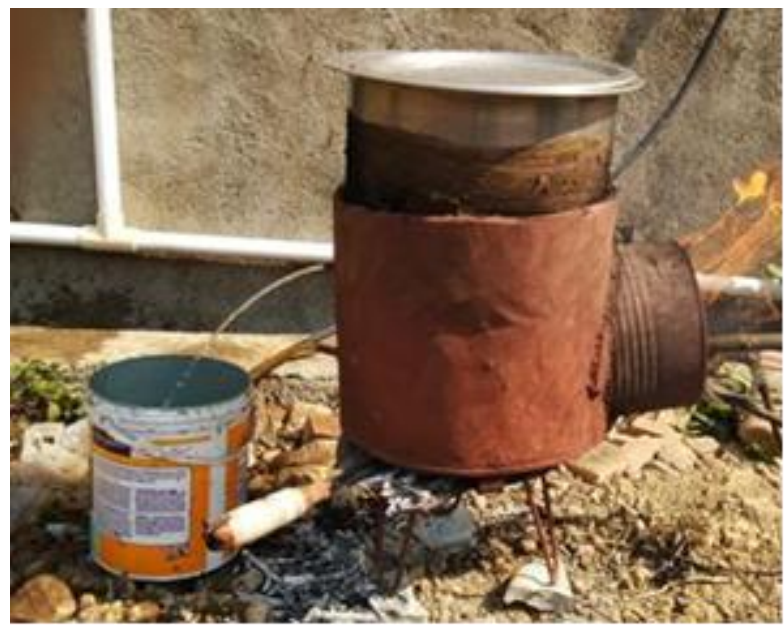

Fig. Timespentincookingtest $(\mathrm{hr} / \mathrm{kg})$ andspecificfuelconsumptionduringCCTof developeddualpurposecookstove

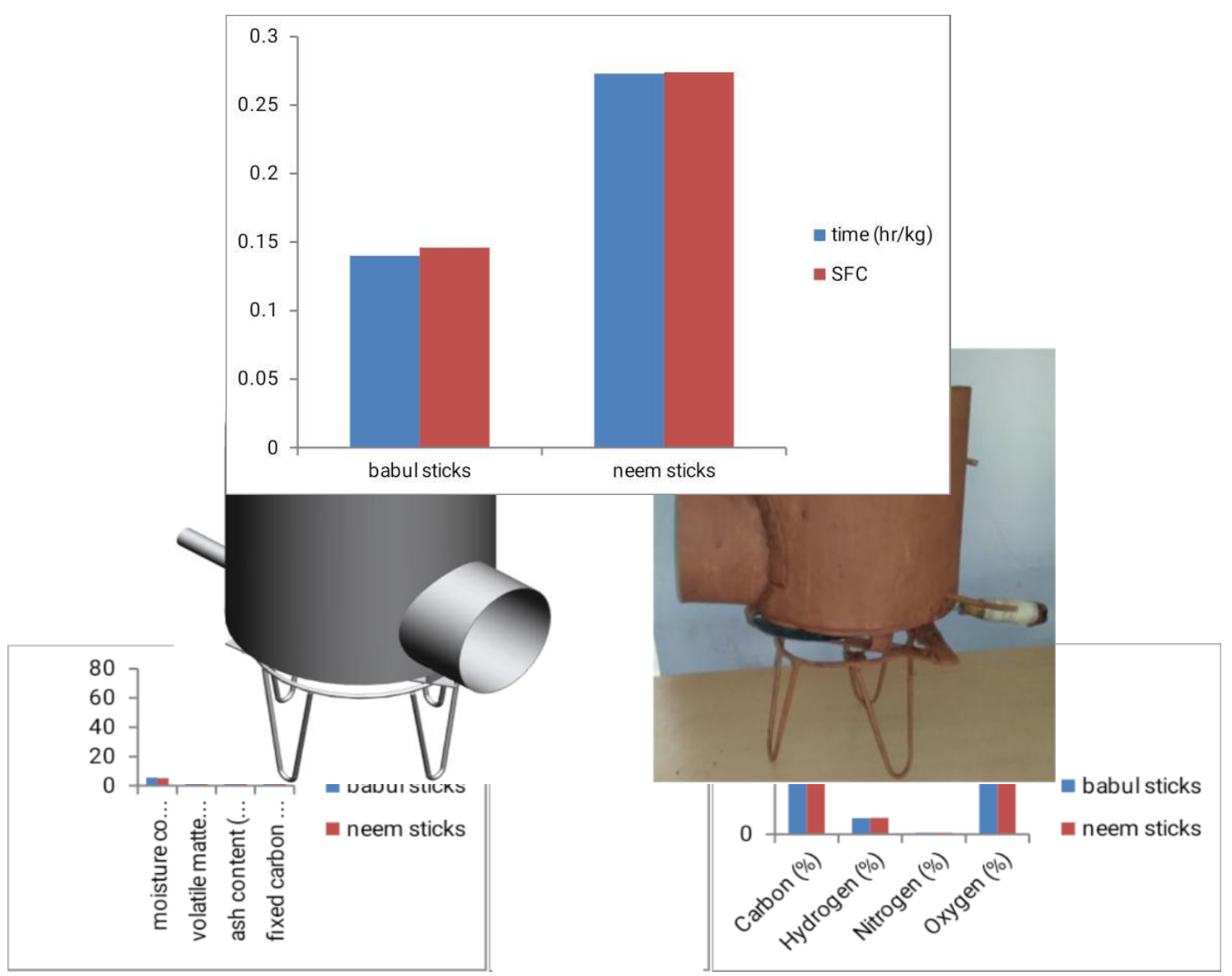

Ultimate analysis of babul sticks and neem sticks
Proximate analysis of babul Sticks and neem sticks 
The conclusions were drawn from the study of developed dual purpose cooks

The average thermal efficiency for developed dual purpose cook stove was found as 14.81 percent and 18.28 percent for babul and neem sticks, respectively.

The power output ratings for developed dual purpose cook stove were found $1.56 \mathrm{~kW}$ and $1.69 \mathrm{~kW}$ for babul and neem sticks.

Specific fuel consumption for developed dual purpose cook stove was found 0.326 and 0.297 for babul and neem sticks, respectively.

\section{References}

Ahuja DR, Josh V, Smith KR and Venkataraman CV(1987). Thermal Performance and Emission Characteristics of Unvented Biomassburning Cookstoves: A Proposed Standard Method for Evaluation, Biomass, Vol.12:247-270.

Anonymous, http://articles.timesofindia.indiatimes.co $\mathrm{m}$

Anonymous, http://cookstoves.lbl.gov Anonymous, https://youtu.be/gQyU4lokVe4 Anonymous, MNRE. Final Report 2010. New Initiative for Development and Deployment of Improved Cookstove:
Recommended Action Plan. Ministry of Non-Conventional Energy Sources. Government of India.

Anonymous. 2000. S. S. Dara. A text book of Engineering Chemistry: 94-97.

Anonymous. 2008. Fabrication and Testing of A Low Cost Domestic Gasifier Stove: Pp. 24-38.

Anonymous. 2008. Notes from Bureau of Energy Efficiency: 8.

Bhattacharya S, Albina D and Khaing A. (2002). Effects of selected parameters on performance and emission of biomass-fired Cookstoves. Biomass and Bioenergy, Vol. 23:387-395.

Bhattacharya SC. (1998). State of the Art of Biomass Combustion', Energy Sources, Part A: Recovery, Utilization, and Environmental Effects, Vol.20 (2): 113135.

Bolaji OB. And Olalusi A. (2009). Development of an Improved Coal Stove for Cooking in Developing Countries, Assumptions University Journal of Technology, Vol.12(3):182187.

Bryden, M., Still D, Scott P, Hoffa G, Ogale D, Bailis R and Goyer K. 2004). Design Principles for Wood Burning Cook Stoves, Aprovecho Research Center/Shell Foundation/Partnership for Clean Indoor Air, USEPA EPA402-K-05_004.

\section{How to cite this article:}

Ghadge, A.S., N.D. Patil, A. J. Chopade, D.M. Rathi and Alaspure, A.V. 2020. Development and Performance of Dual Purpose Cook Stove. Int.J.Curr.Microbiol.App.Sci. 9(06): 1448-1454. doi: https://doi.org/10.20546/ijcmas.2020.906.180 